\title{
STUDENTS' PERCEPTION TOWARDS THE USE OF PICTURES IN WRITING DESCRIPTIVE TEXT
}

\author{
Habibi Nur Hidayanto \\ Institut Agama Islam Negeri Surakarta \\ e-mail : hbbnh10@gmail.com
}

\begin{abstract}
The aims of this study are to find out whether the use of picture can improve the students' writing skill on descriptive text and to find out the implementation of picture as a media in teaching writing on descriptive text. The study was carried out at the seventh grade of SMP Negeri 1 Gemolong Sragen. The sample of the research was the seventh grade of SMP Negeri 1 Gemolong Sragen. The samples were 40 students. The action research design was carried out collaboratively with senior English teachers in observing the implementation of picture as a media in teaching writing on descriptive text. This research consisted of three cycles. Every cycle consisted of three meetings. The results of the study showed that the use of picture as a media can improved the students' writing skills and the class condition became more enjoyable. Key words: Students' Perception, Media, Picture, Descriptive Text, CAR
\end{abstract}

\begin{abstract}
Abstrak
Tujuan dari penelitian ini adalah untuk mengetahui apakah penggunaan gambar dapat meningkatkan keterampilan menulis siswa pada teks deskriptif dan untuk mengetahui penerapan gambar sebagai media dalam mengajar menulis pada teks deskriptif. Penelitian ini dilakukan di kelas tujuh SMP Negeri 1 Gemolong Sragen. Sampel penelitian ini adalah siswa kelas VII SMP Negeri 1 Gemolong Sragen. Sampel berjumlah 40 siswa. Desain penelitian tindakan dilakukan secara kolaboratif dengan guru-guru bahasa Inggris senior dalam mengamati implementasi gambar sebagai media dalam mengajar menulis pada teks deskriptif. Penelitian ini terdiri dari tiga siklus. Setiap siklus terdiri dari tiga pertemuan. Hasil penelitian menunjukkan bahwa penggunaan gambar sebagai media dapat meningkatkan keterampilan menulis siswa dan kondisi kelas menjadi lebih menyenangkan.

Kata Kunci: Persepsi, Media, Gambar, Teks Deskriptif Siswa, CAR
\end{abstract}

\section{INTRODUCTION}

Writing is the activities to express the idea to be known by other people. Writing is such kind of separate acts which huge of simultaneously challenging. Writing is a process to express thought, ideas, opinions, and feeling that can be arranged into some sentences which has certain meaning and can be understandable for others as a mean of communication. Raimes (1983:4) says that writing is a means of communication between reader and writer. Meanwhile, Peter Elbow in Brown (1994: 321) states that there are twostep process in writing, first you figure out your meaning then you put into language.

English in Indonesia is used as a foreign language. Therefore English becomes one of the subject that must be mastered by the students of junior high school. The students of junior high school must be mastered four skill namely listening, speaking, reading, and writing. The aims of Teaching learning English in Junior High School are to have to ability to develop the communication skill in the form of spoken and written to achieve functional literacy, to have the awareness of the importance of English to improve the competitiveness in global society. It is in line with Brown (in Mukminatien, 1991 : 134) states that it is obvious that writing skill is combination between linguistics competence and communicative competence. The first refers to the learner's knowledge of language rules 
whereas the second deals with the English Foreign Language learner's ability to communicate functionally and interactively.

After pre observation and interview with the English teacher and also some students of the junior high school, the researcher found some problems especially in teaching writing on descriptive text. It can be seen from the score of writing skill. The results are shown from the five elements that have been tested by researchers and collaborators. It is identified from five components of writing skill. The average score of five components in the pretest for contents was 70 ; organization was 69 ; grammar was 67 ; vocabulary was 71 ; and mechanic was 72 . The students problem in writing skill were: 1 . it was not easy to the students to construct the ideas into a good paragraph, 2. the students were lack of vocabulary, 3. The students were lack of grammar, 4. The students did not know how to use the punctuation and mechanic.

Those problems were emerged because of some factors: 1. English Teacher mostly used Indonesian language in the process of teaching learning, 2. Teacher did not use media in teaching writing, 3 . the teacher only used student's activity workbook (LKS) in teaching writing.

To overcome the students' problem in writing, the researcher used a media in the form of pictures to solve the problem in writing descriptive text. Pictures is used to stimulate the students in writing teaching, to enjoy writing in the target language, and also to enhance student's motivation in writing. Using picture can stimulate student's imagination so they can show or describe their opinion about the picture. According to Wright (1989:2) pictures can be useful on emphasizing the teaching of writing and speaking, listening and reading. Furthermore, pictures have an important role in delivering the activity of teaching and learning process. Wright (1989:29) emphasizes that pictures can help the learners in terms of retell experience or understand something since they can represent place, objects, people, etc.
Picture as teaching media has many advantages, they are: (1) more realistic than verbal media; (2) can overcome the circumscription of Space and time;(3) can overcome the limitedness of word observation; (4) can clarify a problem, in any field and for any age level, so that it can prevent or correct misunderstandings.; (5) have affordable prices. (Dr.Arif S.Sadimin, M.Sc\&dkk 2007:29).

It can be concluded that picture can support student's creativity and motivation in their learning and finally they can understand better the concept of material. The researcher used pictures as the media to teach writing descriptive because it has many advantages. Pictures and illustrations are enriching in English learning media. As stated by Kinder (1950:102) about the advantages of using picture for writing : (1) students become motivated in the learning writing, (2) as sources material for study in writing, (3) providing artistic and esthetic development, and (4) providing cues which led to creative effort.

The problems that will be examined is: (1) can the use of pictures improve the students' writing skill on descriptive text at the seventh grade of SMP N 1 Gemolong Sragen? And (2) how does the implementation of picture as a media to improve the students' writing skill on descriptive text especially at the seventh grade of SMP N 1 Gemolong Sragen?

\section{LITERATURE REVIEW}

(1) The Nature of Writing

Writing has close relation with reading skill. The student who rend more will write more fluently. What the write is a natural follow-up to what have been read (Cross, 1991: 268). Raimes (1983: 4) says that writing is a means of communication between reader and writer. Meanwhile, Peter Elbow in Brown (1994: 321) states that writing has two-step process, first you figure out your meaning then you put into language.

Cannale and swain (in Mukminatien, 1991: 134) states that there are four important components of writing: discourse, 
grammatical proficiency, strategic proficiency, and sociolinguistics proficiency. The first two are concerned with linguistics and the last two concern with functional aspects of communication. Brown (in Mukminatien, 1991 : 134) states that it is obvious that writing skill is combination between linguistics competence and communicative competence. The first refers to the learner's knowledge of language rules whereas the second deals with the English Foreign Language learner's ability to communicate functionally and interactively.

Writing is one of the language skills that involve many language elements such as: diction, grammar, spelling, punctuation, etc. Murcia (2000:161) states that the writing skill is the most difficult skill if it's compared with the other skills. So no wonder that EFL students think that to be mastered writing skill is difficult because it is requires many aspects of language in its production such as: organization, English rhetoric, diction language use, and mechanics.

It is explained above that the written words is the production of writing. To make the written can be read and understood easily and even can be used as a means of communication is not easy. Of course, a teacher has to consider not only the content of the written text and the way how to express the message in written text but also about the readers reading the text. Brown (1987: 281) states that composition is also defined as the skill of arranging words to form sentences and paragraph, which a teacher further organize them into composition. It means that EFL students have to own a grammatical ability to produce grammatical sentences and arrange them into paragraphs meaningfully in order that they will be able to communicate with others using their thoughts or ideas. Shaw (1986: 3) explains writing is relatively new art form, or process, or means of communication about which little is known. Consequently, it is all more important that the opinion we hold about writing should be accurate and helpful. It means that in writing a text it is very important for EFL students to pay attention not only to the accuracy but also to the existence of their writing in conveying their thought or ideas to others. Of course, it depends on how well they are able to organize their sentences into a text.

Based on the statements above it can be concluded that writing is one of the way to express thought, idea, opinion, and feeling that can be arranged into sentences and can be understandable for others as a mean of communication between writer and readers. It is obvious that producing a qualified a text needs a deep understanding since it involves a number of complicated rhetoric and linguistic problems. For EFL students, they will a lot of time and practice to determine their thoughts and ideas in the form of text that allows them to have better writing and give them the ability to see their own improvement in writing. That is why teacher has to be able to make writing as an interesting classroom or outdoor activity by using many kinds of techniques in conveying teaching material during the teaching-learning process. Of course, having a lot of exercises also takes an important role in this case.

(2) The Nature of Picture

Pictures are photographic (or photographic like) that describe places, people, and objects. Images that are usually used in learning media are photos, postcards, illustrations from books, magazines, catalogs, and so on. (Heinich, Molenda, and Russel, 1993). They also stated using pictures has the advantages. For example, realistic format can be translate become abstract ideas from nonprojected still pictures. They allow instruction to move down from the level of verbal symbols in Dale's cone of experience to a more concrete level. Still pictures are easy to use because using it can be describe many things. They are cheap or no cost. Still pictures can be used in every level of instruction and in all disciplines. According to Wright (1989:2) pictures can be implemented in teaching writing, speaking, listening, and reading. Pictures contribute the students' understanding from the context in general. Meanwhile, Yuswotomo (1991: 14) states that there are two kinds of pictures that can be used for teaching. The first is the original 
pictures and the second is the illustration pictures. The original pictures indicate the real part of the person or objects related to the topic being discussed. The pictures of illustration is made to have imagination a situation or an object needed for the teaching activities such as a conversation's illustration between mother and father in a dining room.

It can be concluded that picture has important role in the teaching learning especially in writing. Students are able to look and explain about the object directly. For students will be easy for them to think and discuss the real object which can be seen. They do not need to imagine about what they should write.

\section{METHOD}

This study was carried out under an action research. Bogdan and Biklen (Bums, 1999:30) states that Action research is the systematically information collection which is designed for social change. This research was a classroom action research which covers observations, analysis and adjustment. Here the researcher with the collaborator arranged the goal of teaching and learning writing process in the classroom to make a better change in classroom practice. A pre research was conducted to find out the students' problem in writing skill. During the writing activities, the researcher observed the teaching and learning process especially teaching writing skill on descriptive text.

The research was implemented in SMP Negeri I Gemolong in Sragen. The subject was the seventh grade, especially in class C of SMP Negeri I Gemolong Sragen. The sample was 40 students. This is the seventh grade students of SMP Negeri I Gemolong Sragen. According to the teacher, this class faced some problems in writing a descriptive text, so it is needed a treatment for them to increase their writing competence.

Kemmis and Mctaggart in Anne (1999:32) states that action research occurs through a dynamic and complementary process which consist of four essential moments of planning, action, observation and reflection. Each moment will be explained below:
1. Planning is the process of constructing an action writing plan to reach the goal of writing descriptive text.

2. Acting; the activities implementation from planning.

3. Observation is an activity of observing the classroom activity of writing to get information from the action.

4. Reflection discuss the weaknesses and strength for every cycles.

\section{The Action Research Procedures}

This research consisted of six steps. Every cycle was started from planning the action until revising the plan. The step of procedures explained as follows:

\section{Problems identification}

It was identified the students' problem in writing skill.

The problems identified using three techniques, they were:

a. Observation

The observation was conducted to get the information about teacher and students activity during the teaching writing.

b. Using test

The pretest was given to know the students' ability in writing descriptive text, especially in the level of competence.

c. Interview

It was conducted by the researcher. The researcher interview the English teacher and some of the students to get the difficulties faced by them in teaching and learning the writing of descriptive text.

2. Planning the action

The action plan arranged before implementing the action. The preparation were:

a. Decided the topic, the topic was descriptive text.

b. Arranged the lesson plan of writing descriptive text and designing the steps in doing the action.

c. Prepared the teaching media (e.g. pictures) 
d. Learning how to convey all the writing descriptive material.

e. Prepared documentation (to take some pictures in the teaching learning process).

f. Prepared observation's sheet to know the teaching and learning process (observe the situation in the classroom, the condition of the students and the process of teaching and learning writing using pictures as a media).

g. Prepared posttest (to know the improvement of students' writing skill on descriptive text).

\section{Implementing the action}

The researcher (also act as teacher) implemented the action. The researcher gave the writing descriptive material to students and asked students to make a paragraph based on the picture given.

4. Observing/monitoring the action

The researcher observed and recorded student's activity during the teaching and learning writing in both written (field note) and visual form (pictures).

5. Reflecting the result of observation The writer asked to the students about their responses during the action based on the treatment. The researcher made some notes and analyzed the students' difficulties during the action and make a revised plan.

6. Revising the plan

The weaknesses from the last cycle were revised to get improvements in the next cycles.

\section{Data Collection}

The researcher collected two kinds of data. They were quantitative data and qualitative data. Quantitative data related to the students' writing scores in pretest and in posttest. The researcher collected quantitative data by using the result of observation and interview. As it is stated by Anna and Hood, document analysis sets out document relevant to the researcher context, e.g. course overviews, lesson plans, student's profile, students' records, classroom materials, assessment tasks.

Qualitative data deals with any occurrences and changes happen during classroom activities. The example of qualitative data were the process of the classroom activity including student's behaviors and classroom situation. The researcher collects the qualitative data by using observation, interview, recording, and field notes.

\section{FINDING}

\section{Cycle 1}

The first was the improvement of writing descriptive. It happened in the process of writing descriptive text, especially in the genre-based approach including BKOF (building knowledge of field), MOT (Modelling of Text), JCOT (Joint Construction of Text), and ICOT (Individual Construction of Text). The stages of this approach could help the students to understand the process in writing descriptive text. It is started in developing the vocabulary, then followed the implementation of the grammar that must be mastered by the students in writing a simple sentences into a simple paragraph.

The result of improvement of elements language (grammar, punctuation, and spelling) in the writing descriptive was low. If the students were analyzed about their writing especially in some aspects, their writing would be known that they did not know about the language elements.

The improvement of the class condition during the teaching and learning process. They were very happy to get some colorful pictures. Using the pictures helped them to be more active and creative in making the outline of the paragraph. It's also improved their relationship among the students, especially in discussion session. They had to complete the new vocabulary task and wrote the simple sentences as the basic of writing descriptive text.

\section{Cycles 2}


The improvement of the student's ability in constructing descriptive text showed in the last stage on the ICOT (Individual Construction of Text). Here students are able to explore the picture, making sentences, and then developing into a descriptive paragraph. Although the improvements were not from all the writing aspects, but it was make their written better than the previous cycle.

The improvement of the student's participation could be seen from their activity in group work. They were more active in the discussion session and helping each other to complete the task.

\section{Cycles 3}

The improvement of the students' writing skill on descriptive text can be seen from the result of their product of writing descriptive text. There were five elements in producing of writing descriptive text and improved significantly, especially in aspects of content, organization, vocabulary, grammar, and mechanic.

Table 1. The Result of Statistical Account

\begin{tabular}{|c|c|c|c|c|c|}
\hline \multirow{2}{*}{ No. } & \multirow[t]{2}{*}{ Points } & \multicolumn{2}{|c|}{ Cycle-1 } & \multirow{2}{*}{$\begin{array}{l}\text { Cycle- } \\
2\end{array}$} & \multirow{2}{*}{\begin{tabular}{l} 
Cycle- \\
\multicolumn{1}{c}{3} \\
Post- \\
test
\end{tabular}} \\
\hline & & $\begin{array}{l}\text { Pre- } \\
\text { test }\end{array}$ & $\begin{array}{l}\text { Post- } \\
\text { test }\end{array}$ & & \\
\hline I & $\begin{array}{l}\text { The } \\
\text { highest } \\
\text { score }\end{array}$ & 76.6 & 78.4 & 82 & 87 \\
\hline 2 & $\begin{array}{l}\text { The } \\
\text { lowest } \\
\text { score }\end{array}$ & 66 & 69 & 72 & 74 \\
\hline 3 & Mean & 70.25 & 72.05 & 74.82 & 77.02 \\
\hline 4 & $\begin{array}{l}\text { Passing } \\
\text { grade }\end{array}$ & 75 & 75 & 75 & 75 \\
\hline
\end{tabular}

From table 1, it can be seen that in the cycle 1 for pretest the highest score was 76.6 while the lowest got 66 with the average score of the class was 70,25. Then in the posttest the highest score 78.4 and 69 for the lowest with the average 72,05 . It mean that in the cycle 1 for the final result were not fulfill for the passing grade.

The improvements appeared in the cycle- 2 and cycle- 3 . In the cycle 2 the highest score was 82 and the lowest was 72 with the average score was 74,82 . For the cycle- 2 the class average was still under the passing grade. And for cycle 3 there were 87 for the highest score and 74 for the lowest with the average 77.02 . In cycle 3 , it can be seen that there was an improvement on students' writing achievement which fulfill the passing grade of writing skill.

Table.2 Element of writing score

\begin{tabular}{r|l|r|r|r}
\hline \multirow{2}{*}{ No } & \multirow{2}{*}{$\begin{array}{c}\text { Elements of } \\
\text { Writing }\end{array}$} & \multicolumn{3}{|c}{ Score } \\
\cline { 3 - 5 } & Cycle 1 & Cycle 2 & Cycle 3 \\
\hline 1 & Contents & 71.57 & 75.4 & 77.07 \\
\hline 2 & Organization & 71.87 & 75 & 76 \\
\hline 3 & Vocabulary & 72.2 & 74.17 & 75.54 \\
\hline 4 & Grammar & 70.05 & 73 & 76.65 \\
\hline & Punctuation \& & & & \\
5 & Mechanic & 74.22 & 76.6 & 79.2 \\
\hline & Average Score & $\mathbf{7 1 . 9 8 2}$ & $\mathbf{7 4 . 8 3 4}$ & $\mathbf{7 6 . 8 9 2}$ \\
\hline
\end{tabular}

The table 2 showed the score of the element of writing. From table 2, it can be seen that there were some improvement for writings' elements. The average score increased from 71.98 in cycle $1,74.83$ in cycle 2 and finally the last score was 76.89 for cycle 3 . It means that, all the elements of writing skill were able to fulfill the passing grade.

The improvements clearly seen in the chart below. In the chart below, it can be seen that the vocabulary was decreasing in the posttest if compared with the pretest. It happened because in this cycle the researcher thought that students were familiar with vocabularies on the picture given. But in the next cycle all the elements of writing skill increased. It can be concluded that using pictures as a media in teaching writing on descriptive text was effective. 


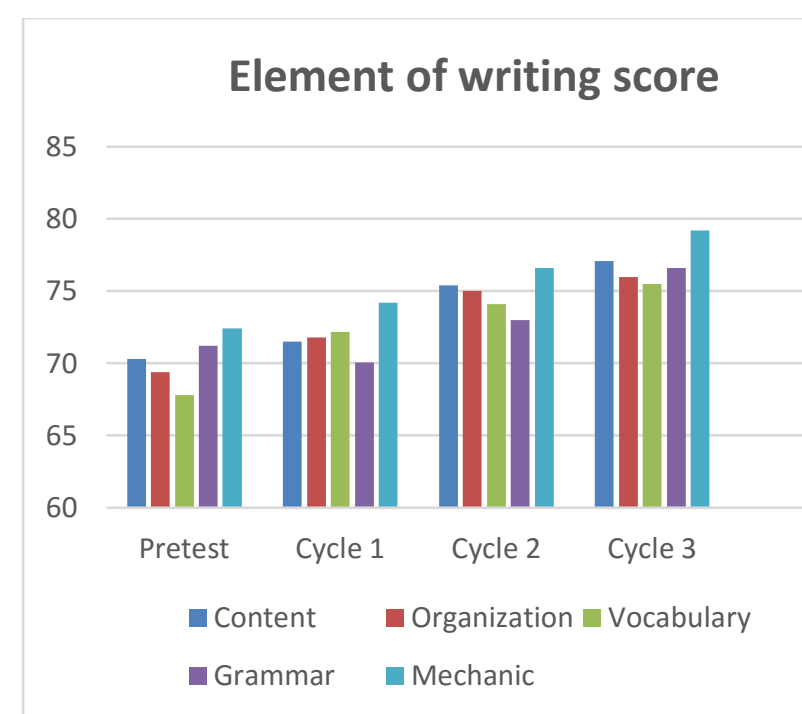

Chart 1. The Elements of Writing Score

\section{DISCUSSION}

The improvements appeared in the cycle 2 and cycle 3 . In the cycle 2 the highest score was 82 and the lowest was 72 with the average 74, 82. For the cycle 2 the class average was still under the passing grade. And for cycle 3 there were 87 for the highest score and 74 for the lowest with the average 77.02. In cycle 3, it can be seen that there was an improvement on students' writing achievement which fulfill the passing grade of writing skill. It means that the use of pictures as media in teaching writing can make the students write a descriptive text easily. There were some improvement based on the components of writing skill, such as Content, grammar, vocabulary, organization of ideas and mechanic. It is in line with Steve Peha (2003) to develop the descriptive text, the students' needs to improve their understanding about the use of language elements. The result of the research in line with the previous research by Susanti (2003) She found that writing using pictures are appropriate to increase the students' writing scores. She also found that in teaching and learning process the students are active and enthusiastic. They feel enjoy and it is interesting activity for them in the writing. The implementation of teaching writing using picture also having positive response from the students.
It means that result of this research improved in every components of writing skill in line with Wright (1989:2) pictures contribute to interest and motivation, a sense of context of the language, and a specific reference point or stimulus. He also stated that picture can be useful on emphasizing the teaching of writing and speaking, listening and reading integrated. The most benefit of a picture can make is to contribute to the student's understanding of a more general context which may be made up of pictures, the teacher's actions, the student's actions, sound effects and words. Furthermore, pictures have an important role in delivering the activity of teaching and learning process. Wright (1989:29) states that students are helped by using picture in terms of retell experience or understand something since they can represent place, objects, people, etc.

\section{CONCLUSION}

The students writing capability were improved significantly. It could be seen from the student's final draft. It was better than before. The students feel easier to develop their idea after using picture as the media, especially in writing descriptive text. They more understand about the use of contents, organization, vocabulary, grammar, and mechanic. Improvement of the students in writing is also supported by improving their vocabularies. The picture has a significant rule to improve the vocabulary of the students. Improvement of the student's vocabulary is rising in joining in English classroom. Their improvement their vocabulary can be seen from their activity in creating and adapting their writing from the pictures. The result of the research in line with Tatum (2008:1-2) Pictures can help the students to learn and comprehend the text. For example, pictures increase comprehension when they: (1) illustrate central information to the text; (2) illustrate new content important to the overall message being presented; (3) help depict the structural relationships covered by the text; and (4) add more meaning to the text, such as in a diagram or illustration. 
Besides that, the class condition became more enjoyable. This improvement can be seen during the process of teaching learning writing on descriptive text in the classroom. The students were very happy to get some color pictures in the lesson. Using pictures make students more active and creative in making the outline, which it help them to write draft more easily. Furthermore, close relationship among the students more tightly, especially in discussing to complete the new vocabulary task and make the simple sentences as the basic of writing description text. In another one picture can make the students want to give pay attention and to take part of the lesson, Andrew Wright (1989: 17).

Students became more active and creative in discuss the task with their group, they tried to finish the tasks on time, and more enthusiastic to join the English classroom. The class member competition is more alive, because they tried to be the first and the right person in finishing the task. It happened in the group works. These condition make the students more interested in doing every assignment of writing from teacher.
Although the results showed the improvement of the students' writing skill, some suggestion still needed for the English teacher to apply this technique; (1) Team work should have arranged well in order to make the group discussion become more alive, (2) Various and colorful pictures should be use by the English teacher to make students become more interesting in doing the written activity; (3) The text should be supported picture; (4) Some pictures criteria should be considered if they were applied, they should be interesting, easy to prepare, meaningful and authentic, easy to organize, and sufficient amount of language; (5) Before making the descriptive text, it is better to the teacher to give the students the rule of writing. Teachers should giving examples and explanation about the text clearly and also knowing that the students are understood well about these materials; (6) Teacher as the facilitator should give clear instruction to the students, to manage the time as effective as possible, to give more control and guidance in group working, and to select topics and picture sequences which are close to the students' life.

\section{REFERENCES}

Arief S Sadiman, dkk. (2007). Media Pendidikan. Jakarta: PT. Raja Grafindo Persada.

Bogdan, R.C., Biklen, S.K. (1982). Qualitative research for education: an introduction to theory and method. Boston: Allyn and Bacon. Inc.

Brown, H. Douglas. (1998). Principle of Language Learning or Teaching. San Francisco: Prentice Hall Inc.

Cahyono,B.Y. and Mukminatien, N. (2011). Techniques and Strategies to Enhance English Language Learning. Malang: State University of Malang Press.

Heinich, R., Molenda, M., dan Russel, J.D. (1982). Instructional Media and The New Technologies of Instruction. New York. John Wiley

Kemmis, S \& Mc Taggart, R. (1992). The Action Research Planner. Australia: Deakin University Press.

Murcia, Marianne Celce and Elite Olshtain. (2000). Discourse Context in Language teaching. United State: Cambridge University.

Raimes, A. (1983). Techniques in teaching writing. Oxford: Oxford University Press.

Susanti, Era (2003) "Improving the Students' Ability in Writing Recount Texts through Picture Sequences at State Islamic Junior High School (MTsN) Lubuk Basung I West Sumatera".

Wright, Andrew. (1992). Pictures for Language Learning. Australia Cambridge University Press

Yuswotomo. (1991). Alat Bantu Mengajar Bahasa Inggris. Malang: Proyek OPF IKIP Malang. 